\title{
Article \\ Identification of Metal Contamination Sources and Evaluation of the Anthropogenic Effects in Soils near Traffic-Related Facilities
}

\author{
Hong-gil Lee $\mathbb{D}^{\mathrm{D}}$, Yoon Joo Byun, Young-Woo Chun, Hoe-Jung Noh, Dong-Jin Kim, Hyun-Koo Kim and Ji-In Kim * \\ Soil and Groundwater Research Division, National Institute of Environmental Research, 42 Hwangyoung-ro, \\ Incheon 22689, Korea; lhg7090@korea.kr (H.-g.L.); yju0902@korea.kr (Y.J.B.); marvelwoo@korea.kr (Y.-W.C.); \\ hjnoh99@korea.kr (H.-J.N.); gimdj83@korea.kr (D.-J.K.); khk228@korea.kr (H.-K.K.) \\ * Correspondence: qwer177@korea.kr; Tel.: +82-325-608-374; Fax: +82-325-634-102
}

check for

updates

Citation: Lee, H.-g.; Byun, Y.J.; Chun, Y.-W.; Noh, H.-J.; Kim, D.-J.; Kim, H.-K.; Kim, J.-I. Identification of Metal Contamination Sources and Evaluation of the Anthropogenic Effects in Soils near Traffic-Related Facilities. Toxics 2021, 9, 278. https:// doi.org/10.3390/toxics9110278

Academic Editor: Manfred Sager

Received: 9 September 2021

Accepted: 19 October 2021

Published: 21 October 2021

Publisher's Note: MDPI stays neutral with regard to jurisdictional claims in published maps and institutional affiliations.

Copyright: (c) 2021 by the authors. Licensee MDPI, Basel, Switzerland. This article is an open access article distributed under the terms and conditions of the Creative Commons Attribution (CC BY) license (https:// creativecommons.org/licenses/by/ $4.0 /)$.

\begin{abstract}
Traffic-related facilities typically have much lower metal emissions than other sources; however, they can be numerous and widespread as well. Subdividing pollution sources is necessary to assess soil contamination characteristics and identify sources according to the contamination cause. Anthropogenic contamination by metals was quantitatively determined using contamination factor (Cf) and evaluated using multivariate analysis. More than half of the concentrations for $\mathrm{Zn}, \mathrm{Pb}$, and $\mathrm{Cu}$ in soils were higher than that in the natural background (NB). Cf of metals was, in decreasing order, $\mathrm{Zn}>\mathrm{Pb}=\mathrm{Cu}>\mathrm{Ni}=\mathrm{As}$. $\mathrm{Zn}, \mathrm{Pb}$, and $\mathrm{Cu}$ were identified as anthropogenic contaminants in correlation analysis. Principal component analysis showed that the two main contamination causes were coarse particles from the maintenance or crushing activities of vehicles and nonexhaust/exhaust emissions. Clusters were classified according to those two anthropogenic and lithogenic causes and included Group I ( $\mathrm{Zn}, \mathrm{Pb}$, and $\mathrm{Cu}$ in garages, auto repair shops, and auto salvage yards), Group II ( $\mathrm{Zn}, \mathrm{Pb}$, and $\mathrm{Cu}$ in parking lots, driving schools, and roadsides), and Group III (As and $\mathrm{Ni}$ with high lithogenic properties). Anthropogenic input and sources of soil contamination by metals in traffic-related facilities were appropriately estimated through the combination of Cf and multivariate analysis.
\end{abstract}

Keywords: metal contamination; anthropogenic contamination; urban traffic; heavy metal

\section{Introduction}

Traffic-related facilities refer to places for vehicle movement and maintenance, such as roads, repair shops, and garages, where contamination may occur locally or in a wide area by many contaminants. These facilities typically have much lower emissions but can be numerous and widespread as well [1,2]. Vehicular traffic and, by implication, road surfaces are among the most important sources of pollutants to the environment [3]. There have been various studies on the pollutants that may be generated in traffic-related facilities [4-10]. Various metals are discharged from automobile emissions, such as vehicles' used oils, worn parts, used batteries, and fuel additives including trace amount of organic and inorganic chemicals, thereby facilitating soil contamination by metals [11,12]. These metals enter human bodies and other ecosystems, such as groundwater, rivers, the atmosphere, and crops, through bioaccumulation in food chains [13-15]. Some metals are essential sources of nutrients for living beings; however, they are generally considered toxic to humans and animals, even at low concentrations, because of their carcinogenic effects [16-20].

Pollution indices (PIs) are techniques to quantify the contamination level of substances of interest in soils by calculating the ratio of the concentration discovered in a site suspected of pollution to the reference concentration (e.g., natural background (NB) or the concentration of a specific element on earth's crust) [21]. They are used to evaluate the pollution level of various environmental media, such as soil, water, and sediments [22-25]. 
Because the contamination factor (Cf) was based on the standardization of a tested element against a reference one, the accuracy of multivariate analysis on soil contamination can be improved. Principal component analysis (PCA) and cluster analysis (CA) are used in the evaluation of anthropogenic contamination factor (Cf) of metals in soils and in the identification of contamination sources [26-28].

Although some studies have been conducted on the soil contamination impact of a traffic-related facility limited to a specific city or road in Korea, few studies have been conducted on various traffic-related facilities nationwide [29-34]. The Surveys of the Actual State of Soil Contamination (SASSC) are the national survey projects that examine regions with a high possibility of soil contamination considering soil contamination sources; the goal of these projects is to prevent hazards on citizens' health and the environment by soil contamination. Traffic-related facilities are considered to be a source of soil contamination in SASSC and are analyzed every year by local governments, who check whether their contamination exceeds the standard limit. Thus, it is necessary to investigate the contamination characteristics, contamination causes, and a correlation between contamination sources and contaminants to provide a measure to control contamination sources. In this study, we (i) distributed the concentrations of metals associated with anthropogenic sources, (ii) evaluated the level of the anthropogenic contamination effect of metals, (iii) evaluated a correlation between metals and each contamination source, and (iv) categorized the contamination sources according to the contamination causes through PCA and CA.

\section{Materials and Methods}

\subsection{Study Area, Sample Collection, and Analysis}

From 2015 to 2019, 2330 soil samples were collected from car dismantling workshops (for recycling), repair shops, parking lots, car schools, garages and their adjacent roadsides throughout the nation. The contamination sources were classified into auto repair shops (ARS), auto salvage yards (ASY), driving schools (DSC), garages (GAR), parking lots (PAL), and roadside (RDS) according to the use of the facility. Port-related facilities and aviation-related facilities were excluded from the evaluation because they exhibited a regional distribution. A summary of the study area is described in Table S1 and Figure S1. Topsoil $(0-15 \mathrm{~cm})$ samples were used for consistent analysis of the contamination phenomenon. It has been known that urban surface soils, including those in the roadside and transportation industries, are indicators of heavy metal contamination from atmospheric deposition [35-37]. Five to ten soil samples in a region were mixed together to prepare a composite soil sample. All samples were decomposed using aqua regia after air drying and sieving (10-100 mesh). The decomposed solution was analyzed with AAS or ICP-AES considering the concentration level of the contaminant to be analyzed and available instruments at each local government. The method detection limit and detection limit (DL) were derived using reference materials before sample analysis begins and were satisfied with the goals of quality control.

In environmental data, data below the DL can be statistically substituted in a variety of ways [38-40]. In this study, it was substituted to DL/2 of each metal to avoid the underestimation of the Cf. The DL for each item is as follows: zinc ( $\mathrm{Zn}), 1.0 \mathrm{mg} \mathrm{kg}^{-1}$; lead $(\mathrm{Pb}), 1.5 \mathrm{mg} \mathrm{kg}^{-1}$; copper $(\mathrm{Cu}), 1.0 \mathrm{mg} \mathrm{kg}^{-1}$; arsenic (As), $0.10 \mathrm{mg} \mathrm{kg}^{-1}$; and nickel (Ni), $0.4 \mathrm{mg} \mathrm{kg}^{-1}$.

\subsection{NB Concentrations and Data Selection}

The NB concentration data of metals in the National Institute of Environmental Research were used [41,42]. The NB areas are unpolluted natural/undisturbed sites which can represent the geological units in Korea (Table S2). The NB levels were as follows: zinc ( $\mathrm{Zn}), 54.3 \mathrm{mg} \mathrm{kg}^{-1}$; lead $(\mathrm{Pb}), 18.4 \mathrm{mg} \mathrm{kg}^{-1}$; $\operatorname{copper}(\mathrm{Cu}), 15.3 \mathrm{mg} \mathrm{kg}^{-1}$; arsenic (As), $6.83 \mathrm{mg} \mathrm{kg}^{-1}$; and nickel (Ni), $17.7 \mathrm{mg} \mathrm{kg}^{-1}$.

801 samples were selected as contaminated samples that have the upper confidence limit of 95 percentile of the NB as per the UK and Netherlands methods. Although these 
methods are somewhat arbitrary, it can guarantee the variability of most NB concentrations, except for extreme values [43-45].

\subsection{Contamination Factor}

Cf allows the assessment of soil contamination based on the concentrations of contaminants referenced to background levels of elements, as presented in Equation (1). The NB concentrations described in Section 2.2 were applied as background levels instead of the pre-industrial levels of metals in sediments suggested by Hakanson (1980) [46].

$$
\mathrm{Cf}=\frac{\text { Measuredconc. ofelement }}{\text { Backgroundconc. ofelement }}
$$

Cf values (unitless) fall into the following four classes: no/low contamination $(\mathrm{Cf}<1)$, moderate contamination $(1 \leq \mathrm{Cf}<3)$, considerable contamination $(3 \leq \mathrm{Cf}<6)$, and very high contamination $(\mathrm{Cf} \geq 6)$.

\subsection{Statistical and Multivariate Analysis}

The data were statistically analyzed using the $\mathrm{R}$ package (version 4.0.2). Since the Shapiro-Wilk test results showed that all data had no normality, a non-parametric analysis significance test was conducted (Table S3). To test if there was a significant difference in variance among data, the Kruskal-Wallis method followed by the post-hoc Dunn test was used. Kendall's correlation was used to analyze the correlation between metal concentrations in each contamination source. The analysis was conducted such that if $\tau$ (tau) was larger than 0.3 , there was a positive correlation, and if the significant level satisfied the $95 \%$ significance level $(p<0.05)$, the correlation was significant. For the PCA among multivariate analyses, the "prcomp" function was used. The Kaiser-Meyer-Olkin (KMO) test was conducted to evaluate the usefulness of the dataset for PCA, and the criterion of the usefulness was set to $>0.5$. For the test of variance homogeneity for non-normal distributions, the Fligner-Killeen test was employed. The absolute loading of each component from the extracted PC was expressed to strong positive loading when its value was more than 0.4. For the hierarchical CA, the Ward algorithmic method and squared Euclidean distance were applied. The data and NB data for each contamination source used in the CA were re-adjusted to $0-100$ percentiles for each contamination source to overcome the data size difference.

\section{Results and Discussion}

\subsection{Distribution of Metals in Soils Nearby Contamination Sources}

The concentration distributions of $\mathrm{Zn}, \mathrm{Pb}$, and $\mathrm{Cu}$ in the soils showed a significant difference according to the contamination source, whereas the concentration distributions of As and Ni had no significant difference in all contamination sources (Tables S4 and S5). The median values $\left(\mathrm{mg} \mathrm{kg}^{-1}\right)$ of the contaminant showed various distributions according to the contamination source: Zn 89.4 (RDS)-128.1 (DSC); Pb 19.3 (PAR)-31.4 (DSC); Cu 21.3 (PAR)-29.1 (ASY); As 2.6 (DSC)-5.2 (ASY); Ni 8.7 (RDS)-16.6 (DSC) (Table 1). The median values of $\mathrm{Zn}, \mathrm{Pb}$, and $\mathrm{Cu}$ were 1.7-2.3 times, 1.2-2.0 times, and 1.6-2.2 times higher than the median values of the NB. In particular, the median value of $Z n$ exhibited the highest contamination level, as it exceeded the maximum value of the NB except for the median values of PAL and RDS. 
Table 1. Distribution of metals in potentially contaminated soils $\left(\mathrm{mg} \mathrm{kg}^{-1}\right)$.

\begin{tabular}{|c|c|c|c|c|c|c|c|}
\hline Source & $n$ & Median & Range & Source & $n$ & Median & Range \\
\hline \multicolumn{4}{|c|}{$\mathrm{Zn}$} & \multicolumn{4}{|c|}{$\mathrm{Pb}$} \\
\hline GAR & 283 & $115.8^{a}$ & 28.7-1810.9 & GAR & 283 & $25.9^{a}$ & $2.4-642.5$ \\
\hline ARS & 201 & $119.2^{\mathrm{a}}$ & $28.4-3372.9$ & ARS & 201 & $22.7^{\mathrm{a}}$ & $4.5-586.8$ \\
\hline ASY & 77 & $112.7^{a b}$ & $36.5-1255.1$ & ASY & 77 & $25.1^{\mathrm{a}}$ & $7.9-304.8$ \\
\hline PAL & 170 & $94.9^{b}$ & $23.8-536.7$ & PAL & 170 & $19.3^{b}$ & $4.1-231.3$ \\
\hline DSC & 41 & $128.1^{\mathrm{a}}$ & $53.2-476.0$ & DSC & 41 & $31.4^{\mathrm{a}}$ & $8.1-289.0$ \\
\hline RDS & 29 & $89.4^{\mathrm{b}}$ & $22.1-246.2$ & RDS & 29 & $21.0^{\mathrm{b}}$ & $3.5-176.6$ \\
\hline NB & 88 & 52 & $21.3-103.4$ & NB & 88 & 15.7 & $4.1-78.3$ \\
\hline \multicolumn{4}{|c|}{$\mathrm{Cu}$} & \multicolumn{4}{|c|}{ As } \\
\hline GAR & 283 & $23.2^{\mathrm{ab}}$ & $0.5-719.1$ & GAR & 283 & $4.2^{\mathrm{a}}$ & $0.15-42.57$ \\
\hline ARS & 201 & $27.7^{\mathrm{a}}$ & $0.5-489.7$ & ARS & 201 & $4.0^{\mathrm{a}}$ & $0.75-40.94$ \\
\hline ASY & 77 & $29.1^{\mathrm{a}}$ & $0.5-438.3$ & ASY & 77 & $5.2^{\mathrm{a}}$ & $0.39-45.83$ \\
\hline PAL & 170 & $21.3^{\mathrm{ab}}$ & $0.5-165.3$ & PAL & 170 & $4.0^{\mathrm{a}}$ & $0.35-39.36$ \\
\hline DSC & 41 & $28.6^{\mathrm{ab}}$ & $0.5-216.4$ & DSC & 41 & $2.6^{\mathrm{a}}$ & $0.11-27.79$ \\
\hline RDS & 29 & $22.3^{\mathrm{ab}}$ & $0.5-132.5$ & RDS & 29 & $4.9^{\mathrm{a}}$ & $0.55-22.10$ \\
\hline NB & 88 & 13 & $2.8-50$ & NB & 88 & 6 & $0.6-20.6$ \\
\hline \multicolumn{4}{|c|}{$\mathrm{Ni}$} & & & & \\
\hline GAR & 283 & $11.0^{\mathrm{a}}$ & $0.2-139$ & & & & \\
\hline ARS & 201 & $12.3^{a}$ & $0.2-90.5$ & & & & \\
\hline ASY & 77 & $14.3^{\mathrm{a}}$ & $0.2-67.7$ & & & & \\
\hline PAL & 170 & $11.3^{a}$ & $0.2-63.3$ & & & & \\
\hline DSC & 41 & $16.6^{\mathrm{a}}$ & $2.3-40.7$ & & & & \\
\hline RDS & 29 & $8.7^{\mathrm{a}}$ & $2.5-37.7$ & & & & \\
\hline NB & 88 & 14.4 & $1.1-114.4$ & & & & \\
\hline
\end{tabular}

a, b, and ${ }^{\mathrm{ab}}$ Results of the post-hoc Dunn test (see Table S3). Groups followed by the same character are not significantly different. GAR, garage; ARS, auto repair shop; ASY, auto salvage yard; PAL, parking lot; DSC, driving school; RDS, roadside; NB, natural background.

Exhaust emissions from the fuel combustion of vehicles and nonexhaust emissions such as tire wear, brake wear, and road abrasion may occur in all contamination sources $[47,48]$. In addition, a number of studies reported that the average concentrations of $\mathrm{Zn}, \mathrm{Pb}$, and $\mathrm{Cu}$ in soils near RDS, ARS, and GAR were higher than the average background and control concentrations [4,7,49-53]. Tens to hundreds ppb of $\mathrm{Zn}, \mathrm{Pb}, \mathrm{Cu}$, $\mathrm{Ni}$, and As may be contained in gasoline and diesel $[47,54,55]$. Zn was contained in a range of $670-1760 \mathrm{mg} \mathrm{kg}^{-1}$ in motor engine oils with an engine wear prevention additive, zinc-dialkyl-dithio-phosphate [56-58]. Tire wear, brake wear, and asphalt road abrasion were also among the contamination sources of metals (including $\mathrm{Zn}, \mathrm{Pb}$, and $\mathrm{Cu}$ ) that may be generated during vehicle driving and braking [48,59-63], and this result indicated that the load of pollutants onto soils increased the concentration of metal contaminants in soil. Thus, the high concentrations of $\mathrm{Zn}, \mathrm{Pb}$, and $\mathrm{Cu}$ in the soils were found as the results of their accumulation on surface soils by automobile-related emissions.

The median values of As and Ni showed a range of $2.6 \mathrm{mg} \mathrm{kg}^{-1}$ (DSC)-5.2 $\mathrm{mg} \mathrm{kg}^{-1}$ (ASY) and $8.7 \mathrm{mg} \mathrm{kg}^{-1}$ (RDS)-16.6 $\mathrm{mg} \mathrm{kg}^{-1}$ (DSC), respectively, which were relatively lower than the median values of As and Ni of the NB (Table 1). A small amount of As has been used for $\mathrm{Pb}$ component enhancement in car batteries, and As has been known to be present in brake and fuel $[64,65]$. Ni could be emitted from tire wear and motor/engine oil spills [65-68]. However, $\mathrm{Ni}$ and As concentrations contained in the fuel, tires, and brakes were considerably lower than that of $\mathrm{Zn}, \mathrm{Pb}$, and $\mathrm{Cu}$. Several studies on contamination sources in urban areas reported that $\mathrm{As} / \mathrm{Ni}$ concentrations in soils was lower than that of other metals or the background level proposed in their studies, including the lithogenic properties [49,69-71]. The effect of As and Ni soil deposition in soil near the traffic-related facilities was considered lower than $\mathrm{Zn}, \mathrm{Pb}$, and $\mathrm{Cu}$ deposition. 


\subsection{Contamination Factor}

$\mathrm{CfZn}, \mathrm{CfPb}$, and $\mathrm{CfCu}$ in soils near GAR, ARS, ASY, and DSC showed moderate to very high level of contamination in more than $2 / 3$ of the total surveyed area for each contamination source, which verified the anthropogenic contaminations by $\mathrm{Zn}, \mathrm{Pb}$, and $\mathrm{Cu}$ (Figure 1a-c,e). CfAs and CfNi in the soils showed no or low levels of contamination in around up to $3 / 4$ of the samples, which revealed lower anthropogenic effects than that of $\mathrm{CfZn}, \mathrm{CfPb}$, and $\mathrm{CfCu}$. The contamination level of $\mathrm{Zn}$ was evaluated as the most severe in all contamination sources, and the $\mathrm{Cf}$ values were, in decreasing order, $\mathrm{Zn}>\mathrm{Pb} \fallingdotseq \mathrm{Cu}>\mathrm{As}$ $\fallingdotseq \mathrm{Ni}$. The highest $\mathrm{Cf}$ values in the contamination sources were as follows: $\mathrm{Zn} 62.1$ in ARS; $\mathrm{Cu} 47.0$ and 28.7, respectively, in GAR and ASY; Pb 15.7 in DSC.
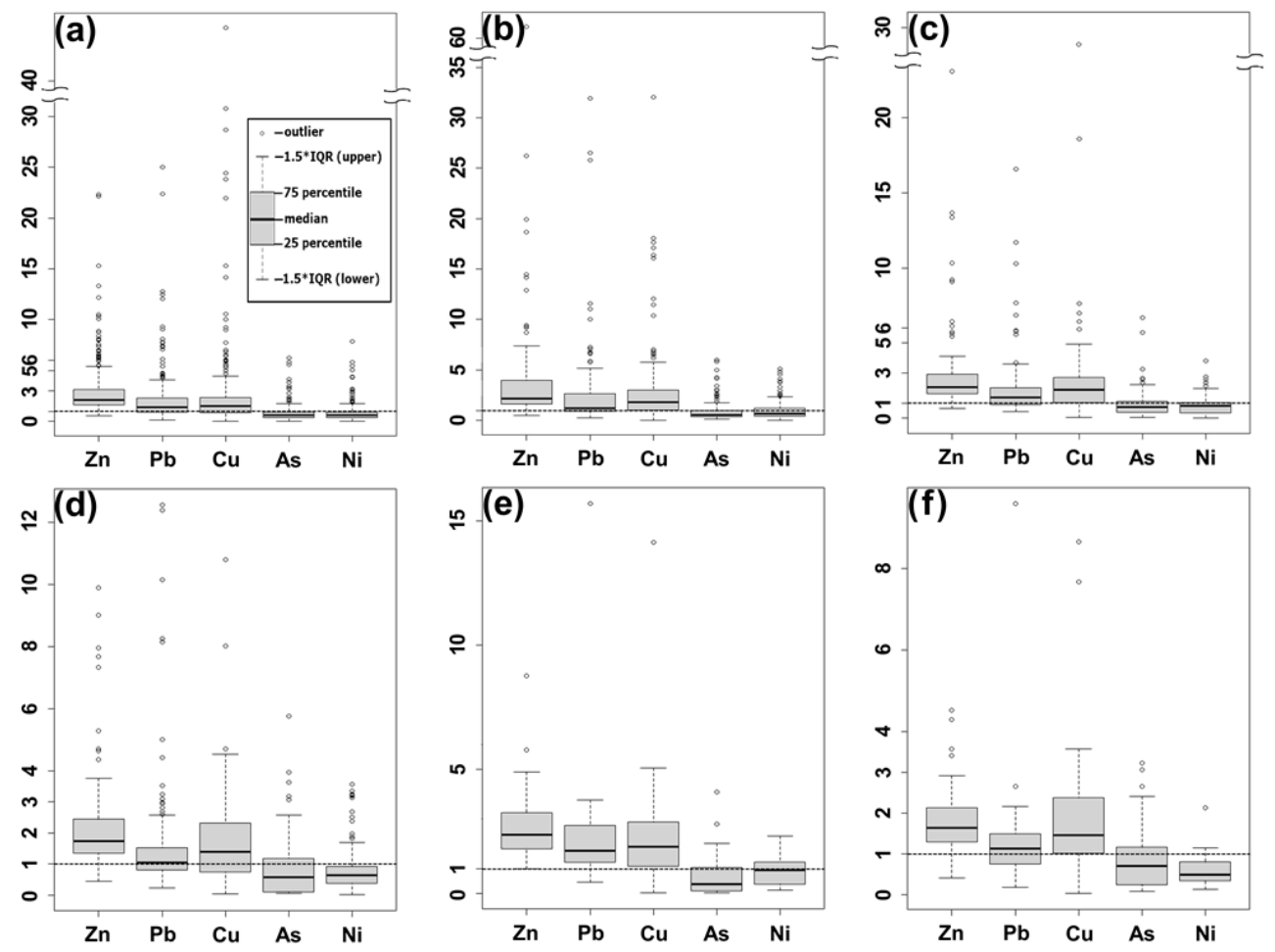

Figure 1. Contamination factors of metals in selected contamination sources; (a) garages (GAR), (b) auto repair shops (ARS), (c) auto salvage yards (ASY), (d) parking lots (PAL), (e) driving schools (DSC), (f) roadside (RDS).

Over half of the soil samples in PAL and RDS demonstrated moderate to very high levels of contamination for $\mathrm{Zn}, \mathrm{Cu}$, and $\mathrm{Pb}$, while CfAs and $\mathrm{CfNi}$ showed no or low levels of contamination at more than $69 \%$ of soil samples from those sources (Figure 1d,f). The Cf values were, in decreasing order, $\mathrm{Zn}>\mathrm{Cu}>\mathrm{Pb}>\mathrm{As}>\mathrm{Ni}$. The highest $\mathrm{CfAs}$ and $\mathrm{CfNi}$ were 5.8 and 3.6 at PAL (considerable to very high levels of contamination), and 3.2 and 2.1 at RDS (moderate to considerable levels of contamination). Their Cfs were lower than that of $\mathrm{CfZn}, \mathrm{CfPb}$, and $\mathrm{CfCu}$ (very high levels of contamination).

\subsection{Correlation Analysis}

Positive correlations among $\mathrm{CfZn}, \mathrm{CfPb}$, and $\mathrm{CfCu}$ were found in the GAR, ARS, and ASY soils $(p<0.005)$ (Table 2). The $\mathrm{Zn}, \mathrm{Pb}$, and $\mathrm{Cu}$ concentrations in soils of ASY were higher than those of the background site, in which auto-related parts were presumed as major contamination sources [8]. $\mathrm{Zn}, \mathrm{Pb}$, and $\mathrm{Cu}$ are the most common metals released from automobiles, accounting for at least $90 \%$ of the total metals in road runoff [60]. Thus, $\mathrm{Zn}$, $\mathrm{Pb}$, and $\mathrm{Cu}$ were anthropogenically accumulated in the soil via vehicle-related emissions during automobile repair or salvage processes. 
Table 2. Correlation analysis between the contamination factors (Cfs) of metals in contaminated soils by Kendall's method.

\begin{tabular}{|c|c|c|c|c|c|c|c|c|c|}
\hline Element & Zn & $\mathbf{P b}$ & $\mathrm{Cu}$ & As & Element & Zn & $\mathrm{Pb}$ & $\mathrm{Cu}$ & As \\
\hline \multicolumn{5}{|c|}{ Garage (GAR) } & \multicolumn{5}{|c|}{ Auto repair shop (ARS) } \\
\hline $\mathrm{Pb}$ & $0.454^{* * *}$ & - & - & - & $\mathrm{Pb}$ & $0.481^{* * *}$ & - & - & - \\
\hline $\mathrm{Cu}$ & $0.399 * * *$ & $0.445^{* * *}$ & - & - & $\mathrm{Cu}$ & $0.441^{* * *}$ & $0.422^{* * *}$ & - & - \\
\hline As & $0.190 * * *$ & $0.210^{* * *}$ & $0.278^{* * *}$ & - & As & $0.130 *$ & $0.222^{* * *}$ & $0.206^{* * *}$ & - \\
\hline $\mathrm{Ni}$ & $0.164^{* * *}$ & $0.169 * * *$ & $0.342^{* * *}$ & $0.209^{* * *}$ & $\mathrm{Ni}$ & $0.400 * *$ & $0.175^{* * *}$ & $0.420 * * *$ & $0.237^{* * *}$ \\
\hline \multicolumn{5}{|c|}{ Auto salvage yard (ASY) } & \multicolumn{5}{|c|}{ Parking lot (PAL) } \\
\hline $\mathrm{Pb}$ & $0.386^{* * *}$ & - & - & - & $\mathrm{Pb}$ & $0.349^{* * *}$ & - & - & - \\
\hline $\mathrm{Cu}$ & $0.357^{* * *}$ & $0.435^{* * *}$ & - & - & $\mathrm{Cu}$ & $0.368^{* * *}$ & $0.295^{* * *}$ & - & - \\
\hline As & -0.013 & $0.294^{* * *}$ & 0.138 & - & As & 0.123 * & $0.243^{* * *}$ & $0.220^{* * *}$ & - \\
\hline $\mathrm{Ni}$ & $0.168^{*}$ & $0.328 * *$ & $0.389^{* * *}$ & $0.249^{* *}$ & $\mathrm{Ni}$ & $0.146^{* *}$ & $0.155^{* *}$ & $0.380^{* * *}$ & $0.159 * *$ \\
\hline \multicolumn{5}{|c|}{ Driving school (DSC) } & \multicolumn{5}{|c|}{ Roadside (RDS) } \\
\hline $\mathrm{Pb}$ & $0.441^{* * *}$ & - & - & - & $\mathrm{Pb}$ & 0.123 & - & - & - \\
\hline $\mathrm{Cu}$ & $0.300^{* *}$ & $0.373^{* * *}$ & - & - & $\mathrm{Cu}$ & 0.005 & $0.379^{* * *}$ & - & - \\
\hline As & 0.184 & $0.234^{*}$ & $0.336^{* *}$ & - & As & 0.135 & $0.354^{* *}$ & 0.249 & - \\
\hline $\mathrm{Ni}$ & 0.127 & 0.236 * & $0.337^{* *}$ & 0.248 * & $\mathrm{Ni}$ & 0.193 & 0.128 & 0.069 & 0.200 \\
\hline
\end{tabular}

$\mathrm{CfNi}$ in the soil among the three contamination sources had a positive correlation with $\mathrm{CfCu}$ and $\mathrm{CfZn}, \mathrm{CfCu}$ and $\mathrm{CfPb}$, and $\mathrm{CfCu}$. Tires and brakes in vehicles contain not only $\mathrm{Zn}, \mathrm{Pb}$, and $\mathrm{Cu}$ but also $\mathrm{Ni}$ [72]. Therefore, the correlation of Ni with other metals was caused by the different loading of nonexhaust particles according to the vehicle types and conditions. This correlation can also be verified from several studies, in which the concentrations of $\mathrm{Ni}, \mathrm{Zn}, \mathrm{Pb}$, and, $\mathrm{Cu}$ in soils near auto-mechanic shops, salvage yards, and electronic waste treatment plants showed significant decreases depending on the horizontal distance from the contamination sources [73-76]. CfAs in the soil among the three contamination sources showed a similar correlation as that of the metals, but its correlation coefficient was lower than that of other elements $(\tau<0.3)$. This tendency seemed to be the result of arsenic usages in automobile-related parts, but its amount was considerably lower than that of other metals.

Correlations between $\mathrm{CfZn}-\mathrm{CfPb}, \mathrm{CfZn}-\mathrm{CfCu}$, and $\mathrm{CfNi}-\mathrm{CfCu}$ in PAL were positive $(p<0.005)$. In addition, a positive correlation between $\mathrm{CfCu}-\mathrm{CfPb}$ was found, but it was statistically weak $(\tau<0.3$ ) (Table 2). Not only was the average concentration of $\mathrm{Zn}, \mathrm{Pb}$, and $\mathrm{Cu}$ in the soils of the parking lot and trailer park in use higher than their average background concentration, but also, the coefficient of variance was more than around twice that of other elements, and the contamination in the parking lot soil was assumed to be caused by parts of different vehicles [7,10]. In addition, the metal amount in the road dust per unit area in the parking lot was as follows: $\mathrm{Zn}>\mathrm{Pb}>\mathrm{Cu}>\mathrm{Ni}>\mathrm{As}$ [51]. Therefore, the correlation between metal concentrations found in the parking lot soils might be determined by the vehicle type.

There was a positive correlation between $\mathrm{CfZn}-\mathrm{CfPb}, \mathrm{CfPb}-\mathrm{CfCu}, \mathrm{CfAs}-\mathrm{CfCu}$, and $\mathrm{CfNi}-\mathrm{CfCu}$ in DSC $(p<0.01)$ (Table 2). Generally, a regular number of vehicles are continuously driven in DSC, and a land boundary is fenced by walls. Nonexhaust or exhaust emissions by vehicles are not easily diffused in the atmosphere and have more chances to deposit in the land. As a result, the correlation between metal concentrations was higher than that of PAL and RDS.

In RDS, there was a positive correlation between $\mathrm{CfPb}-\mathrm{CfCu}$ and between $\mathrm{CfPb}-\mathrm{CfAs}$, but the correlation coefficient between $\mathrm{CfPb}$ and $\mathrm{CfCu}$ was lower than that in GAR, ARS, and ASY (Table 2). This was because RDS is mainly located near the expressways, and the distance between road and soil was sufficiently more than that of other contamination sources, which made it difficult for contaminants to reach the soil. Studies by Akbar et al. (2006) [9] and Nabulo et al. (2006) [77], also supported this hypothesis that as the distance 
between the road and contamination source increased, the metal concentration decreased, and the concentration of metals was observed at the level of NB at around $30 \mathrm{~m}$ distance from the road $[9,77]$. That is, the metal accumulation level in the soil around the road depends on the distance between the road and contamination source.

\subsection{Multivariate Analysis}

\subsubsection{Principal Component Analysis}

PCA results for all pollution sources were considered as useful (KMO values 0.54 to 0.78 ), and the contamination level of each metal at specific sources had no equality of variances $(p<0.005)$ (Table S6). Two components (PC1 and PC2) whose standard deviation was the largest in all contamination sources were extracted (Table S7).

\section{Garage, Auto Repair Shop and Auto Salvage Yard}

In GAR, ARS, and ASY, the first components (PC1) are responsible for $47.8-58.3 \%$ of the total variance and significant positive loadings are shown for $\mathrm{Zn}, \mathrm{Pb}$, and $\mathrm{Cu}$ (Figure 2a-c; Table S8). Because mainly vehicle maintenance or dismantling rather than vehicle driving occurred in these sources, the effect of nonexhaust emissions was more significant than that of exhaust emissions. According to Pant and Harrison (2013) [59], metals can be emitted from various exhaust-related parts, such as fuel/lubricant combustion and engine corrosion, but the level of trace elements emitted in the exhaust is very low and many of these appear most likely to arise from nonexhaust sources. Thus, the load of $\mathrm{Zn}$, $\mathrm{Pb}$, and $\mathrm{Cu}$ in the soils due to anthropogenic effects was extracted as the common factor (PC1).
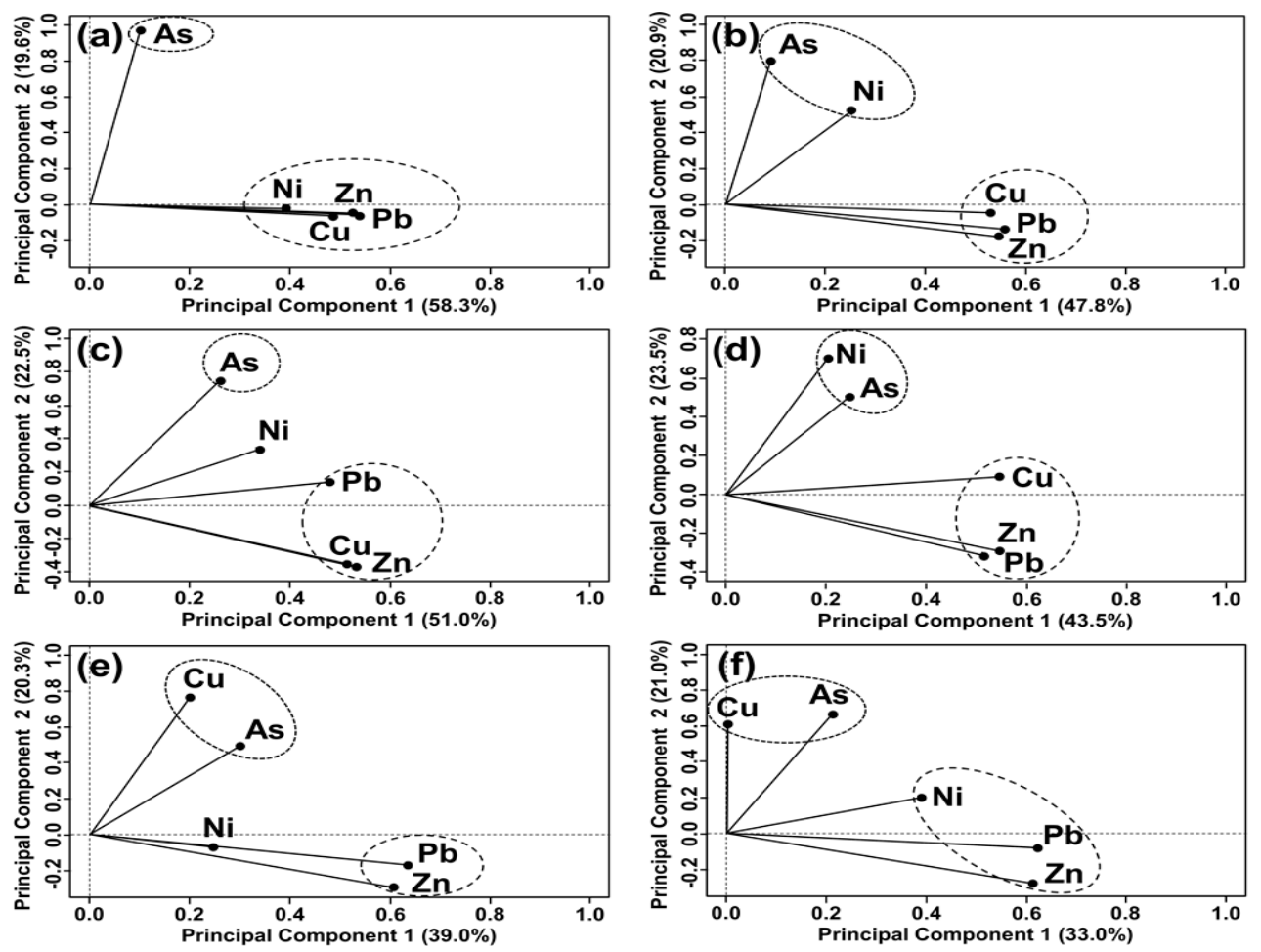

Figure 2. Extracted principal components (PCs) in selected contamination sources: (a) garage (GAR), (b) auto repair shop (ARS), (c) auto salvage yard (ASY), (d) parking lot (PAL), (e) driving school (DSC), and (f) roadside (RDS). The dotted lines represent the xy axis.

PC2 is responsible for $19.6-22.5 \%$ of the total and showed significant positive loadings for CfAs (0.767-0.994) (Figure 2a-c; Table S6). Since As was mostly affected by the lithogenic effect, it was determined that PC2 was the lithogenic factor. PC2 (0.528) and PC1 (0.402) showed a significant positive load for Ni in ARS and GAR. ARS and GAR had a place 
for vehicle maintenance in common, but the latter was more focused on vehicle storage. Despite Ni concentration in ARS and GAR showing close correlations with $\mathrm{Cu}$ or $\mathrm{Zn}$ concentrations and its anthropogenic effects being verified, the PCA result led to a different interpretation. In ASY, PC1 and PC2 exhibited a comparable positive load for Ni (0.348 and 0.345 , respectively). Since stored or piled vehicles in ASY were expired or malfunctioning, the positive load of PC1 was interpreted as the result of the accumulation of coarse particles, including Ni compounds, from the vehicles on the soil surface. Furthermore, since CfNi for some hotspots found in ASY showed relatively low levels of contamination, PC2 (naturaloriginated) may have a positive loading for Ni. Nonetheless, PC1 explained the variance of ASY better. Ni in soils for ASY demonstrated that anthropogenic effects were higher than the geological properties.

Parking Lot, Driving School, and Roadside

In PAL, DSC, and RDS, the first component (PC1) is responsible for $33.0-43.5 \%$ of the total variance and shows significant positive loadings for $\mathrm{Zn}$ and $\mathrm{Pb}$ (Figure 2d-f; Table S6). These contamination sources are characterized by vehicle stay for a certain period or vehicle movement. The amount of metal produced by tires based on the vehicle running distance data in 2010 in Korea calculated using the German informative inventory report (2012) was $208,739 \mathrm{~kg}$ of $\mathrm{Zn}$ and $220.94 \mathrm{~kg}$ of $\mathrm{Pb}$ [78,79], and the amount of harmful components in brake pads in Korea calculated based on the USEPA emission factor was $71.757 \mathrm{~kg}$ of $\mathrm{Zn}$ and $15,790 \mathrm{~kg}$ of $\mathrm{Pb}[79,80]$. Thus, the accumulation of nonexhaust emission of $\mathrm{Zn}$ and $\mathrm{Pb}$ into the soils may occur due to these contamination sources. In PAL, a vehicle exit and entry cycle is generally shorter compared to that of other sources, while the frequency of using a brake is higher within PAL. Brake wear has been used as the key tracer of nonexhaust particles, including $\mathrm{Cu}$ [81-83]. The trend of soil deposition of $\mathrm{Cu}$ caused by the brake pad friction and tire wear was exhibited in PCA.

The second principal component (PC2) displays $20.3-23.5 \%$ of the total variance with high loadings of As (0.509-0.685), $\mathrm{Ni}(0.726)$ for PAL, and $\mathrm{Cu}(0.784,0.682)$ for DSC and RDS, respectively (Figure 2d-f; Table S6). According to Gustafsson et al. (2008), the amount of particulate matter generated from vehicles increases with increasing speeds over $30 \mathrm{~km} \mathrm{~h}^{-1}$ [84]. However, high-speed driving rarely occurs in the testing field of DSC; therefore, it was expected that a relatively lower amount of particulates from exhaust gas might be generated from vehicles in DSC than other contamination sources. In RDS, anthropogenic effects caused by $\mathrm{Cu}$ were low, because generally, RDS was a place at least $100 \mathrm{~m}$ away from the expressway and the frequency of brake use while driving in the highway was relatively lower than that in other roads. The PC2 of the corresponding contamination source explained this trend well.

\subsubsection{Cluster Analysis}

Cfs of metals in all anthropogenic sources were divided into the following three groups: Group I ( $\mathrm{Zn}, \mathrm{Pb}$, and $\mathrm{Cu}$ in ARS, GAR, ASY), Group II ( $\mathrm{Zn}, \mathrm{Pb}$, and $\mathrm{Cu}$ in DSC, RDS, PAL), and Group III (As and Ni in all sources) (Figure 3). For Group I, relatively coarse particles were estimated as the common contaminants during vehicle maintenance or dismantling processes. They accumulated in the soil surface inside or outside the land due to atmospheric events. The contaminants of Group II were the same as those in Group I, but they formed a separate cluster. Group II may contain the impacts of nonexhaust emissions (tire wear) and exhaust emissions while driving, but it formed a cluster closer to Group III. Thus, anthropogenic effects and lithogenic factors were mixed to affect the contamination degrees of $\mathrm{Zn}, \mathrm{Pb}$, and $\mathrm{Cu}$ in Group II soils. As and Ni (Group III) formed different clusters apart from Group I with anthropogenic properties. In addition, they were grouped with metals of NB for CA in each contamination source (Figure S2a-f). Even though As and $\mathrm{Ni}$ were contained in small amounts as parts of automobiles, their lithogenic characteristics were verified again in CA. 


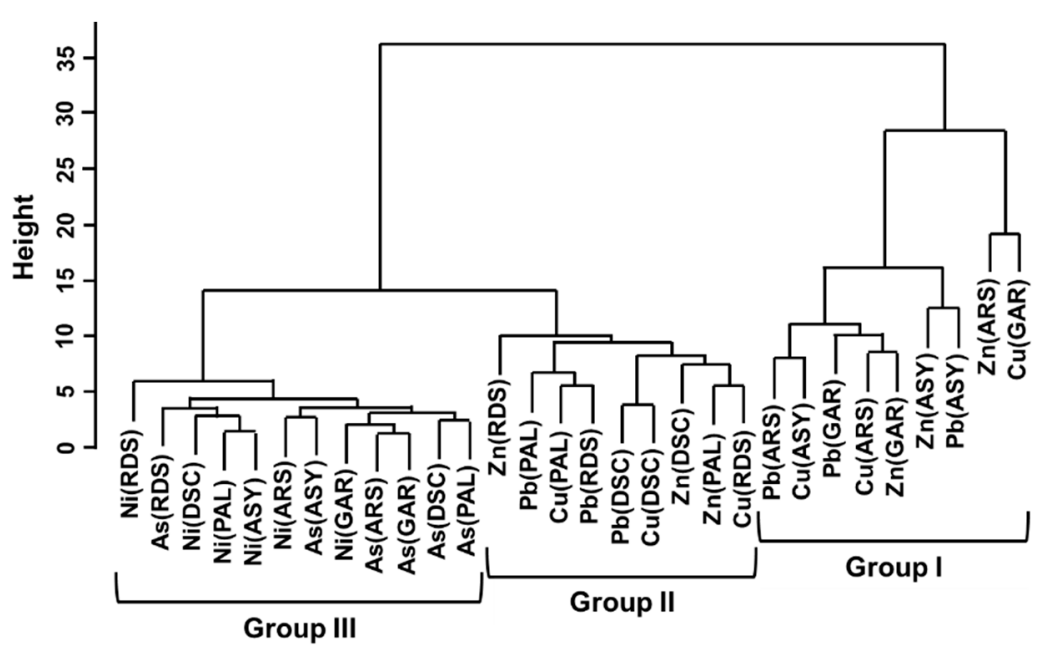

Figure 3. Groups according to the contamination factor (Cf) of metals for each contamination source.

\section{Conclusions}

The concentration distribution of $\mathrm{Zn}, \mathrm{Pb}$, and $\mathrm{Cu}$ near traffic-related facilities was higher than that of NB. The $\mathrm{Cf}$ of metals was, in decreasing order, $\mathrm{Zn}>\mathrm{Pb}=\mathrm{Cu}>\mathrm{Ni}=$ As. $\mathrm{Zn}, \mathrm{Pb}$, and $\mathrm{Cu}$ were identified as anthropogenic contaminants and showed significant positive correlations. PCA revealed two contamination causes by metals: coarse particles emitted during the maintenance and dismantling of vehicles in GAR, ARS, and ASY, and nonexhaust/exhaust emissions from driving or parking cars in PAL, DSC, and RDS. Anthropogenic and lithogenic causes were classified as: $\mathrm{Group} \mathrm{I}(\mathrm{Zn}, \mathrm{Pb}$, and $\mathrm{Cu}$ in GAR, ARS, and ASY), Group II ( $\mathrm{Zn}, \mathrm{Pb}$, and $\mathrm{Cu}$ in PAL, DSC, RDS), and Group III (As and Ni in all sources). Not only the anthropogenic level of contaminants but also common causes of the soil contamination by metals can be estimated in traffic-related facilities through the combination of the PIs and multivariate analysis. Further study of several potentially contaminated areas will be needed for efficient soil environment management in urban regions affected by anthropogenic activities.

Supplementary Materials: The following are available online at https: / www.mdpi.com/article/10 .3390 /toxics9110278/s1: Figure S1: 801 sampling sites in the study area, including garages (GAR), auto repair shops (ARS), auto salvage yards (ASY), parking lots (PAL), driving schools (DSC), and roadside (RDS); Figure S2: Groups according to metal contamination degree for each contamination source and natural background (NB);Table S1: Summary of the study area; Table S2: Distribution of natural background soil samples in Korea; Table S3: Test of normality involving the concentration of metals in concerned areas (Shapiro-Wilk test); Table S4: Significance of differences in metal concentration for soils in concerned areas; Table S5: Post-hoc Dunn test with characters; Table S6: Kaiser-Meyer-Olkin (KMO) and Fligner-Killeen tests; Table S7: Importance of components for each contamination source; Table S8: Extracted PCs and their rotated loadings.

Author Contributions: Conceptualization, J.-I.K.; methodology, J.-I.K., H.-g.L.; software, H.-g.L.; validation, H.-g.L., J.-I.K.; formal analysis, H.-g.L., J.-I.K., Y.J.B.; investigation, Y.J.B., Y.-W.C.; resources, H.-K.K.; data Curation, J.-I.K., H.-J.N., D.-J.K., H.-K.K.; writing—original draft preparation, H.-g.L.; writing-review \& editing, J.-I.K., H.-J.N., D.-J.K., H.-K.K.; visualization, H.-g.L., Y.-W.C.; supervision, J.-I.K., H.-J.N.; project administration, H.-K.K., J.-I.K.; funding acquisition, J.-I.K. All authors have read and agreed to the published version of the manuscript.

Funding: This work was supported by a grant from the National Institute of Environment Research (NIER), funded by the Ministry of Environment (MOE) of the Republic of Korea (NIER-2020-01-01066).

Institutional Review Board Statement: Not applicable.

Informed Consent Statement: Not applicable. 
Data Availability Statement: Data will be available with permission of the National Institute of Environmental Research (NIER).

Conflicts of Interest: The authors declare that they have no conflict of interest.

$\begin{array}{ll}\text { Abbreviations } \\ \text { ARS } & \text { auto repair shop } \\ \text { ASY } & \text { auto salvage yard } \\ \text { CA } & \text { cluster analysis } \\ \text { Cf } & \text { Contamination factor } \\ \text { DSC } & \text { driving school } \\ \text { GAR } & \text { garage } \\ \text { NB } & \text { natural background (level of soil in Korea) } \\ \text { PAL } & \text { parking lot } \\ \text { PCA } & \text { principal component analysis } \\ \text { RDS } & \text { roadside. }\end{array}$

\section{References}

1. US EPA. Reducing Emissions of Hazardous Air Pollutants: What Is being Done to Reduce Hazardous Air Pollutants? Available online: https:/ / epa.gov/haps/reducing-emissions-hazarouds-air-pollutants (accessed on 13 January 2021).

2. Markiewicz, A.; Björklund, K.; Eriksson, E.; Kalmykova, Y.; Strömvall, A.-M.; Siopi, A. Emissions of organic pollutants from traffic and roads: Priority pollutants selection and substance flow analysis. Sci. Total Environ. 2017, 580, 1162-1174. [CrossRef] [PubMed]

3. Goonetilleke, A.; Wijesiri, B.; Bandala, E.R. Water and Soil Pollution Implications of Road Traffic. In Environmental Impacts of Road Vehicles: Past, Present and Future; Royal Society of Chemistry: Cambridge, UK, 2017; pp. 86-106.

4. Wang, M.; Zhang, H. Accumulation of Heavy Metals in Roadside Soil in Urban Area and the Related Impacting Factors. Int. J. Environ. Res. Public Health 2018, 15, 1064. [CrossRef] [PubMed]

5. Mireles, F.; Davila, J.; Pinedo, J.; Reyes, E.; Speakman, R.; Glascock, M.D. Assessing urban soil pollution in the cities of Zacatecas and Guadalupe, Mexico by instrumental neutron activation analysis. Microchem. J. 2012, 103, 158-164. [CrossRef]

6. Mihailović, A.; Budinski-Petković, L.; Popov, S.; Ninkov, J.; Vasin, J.; Ralević, N.; Vasić, M.V. Spatial distribution of metals in urban soil of Novi Sad, Serbia: GIS based approach. J. Geochem. Explor. 2015, 150, 104-114. [CrossRef]

7. Yang, J.; Zhang, C.; Tang, Y. Metal distribution in soils of an in-service urban parking lot. Environ. Monit. Assess. 2015, 187, 478. [CrossRef] [PubMed]

8. Barbosa, J.Z.; Poggere, G.C.; Teixeira, W.W.R.; Motta, A.C.V.; Prior, S.A.; Curi, N. Assessing soil contamination in automobile scrap yards by portable X-ray fluorescence spectrometry and magnetic susceptibility. Environ. Monit. Assess. 2019, 192, 1-10. [CrossRef]

9. Farooq, A.K.; Hg, H.W.; Mohammad, A.A.D.H.A. Heavy Metal Contamination of Roadside Soils of Northern England. Soil Water Res. 2013, 1, 158-163. [CrossRef]

10. Adedeji, O.H.; Olayinka, O.O.; Oyebanji, F.F. Assessment of traffic related metals pollution of roadside soils in emerging urban centres in Ijebu-North area of Ogun state, Nigeria. J. Appl. Sci. Environ. Manag. 2013, 17, 509-514.

11. European Environment Agency (EEA). EMEP/EEA Air Pollutant Emission Inventory Guidebook 2019-Update Oct. 2020. Available online: https:/ / www.eea.europa.eu/ds_resolveuid/SHNJDK8413 (accessed on 2 December 2020).

12. Ciarkowska, K.; Gambus, F.; Antonkiewicz, J.; Koliopoulos, T. Polycyclic aromatic hydrocarbon and heavy metal contents in the urban soils in southern Poland. Chemosphere 2019, 229, 214-226. [CrossRef]

13. Bradl, H. Chapter I: Sources and Origins of Metals. In Metals in the Environment: Origin, Interaction and Remediation; Bradl, H.B., Ed.; Elsevier Academic Press: London, UK, 2005; Volume 6, pp. 1-25.

14. Tchounwou, P.B.; Yedjou, C.G.; Patlolla, A.K.; Sutton, D.J. Heavy Metal Toxicity and the Environment. In Heavy Metal Toxicity and the Environment; Springer: Berlin/Heidelberg, Germany, 2012; Volume 101, pp. 133-164.

15. Jia, Z.; Li, S.; Wang, L. Assessment of soil heavy metals for eco-environment and human health in a rapidly urbanization area of the upper Yangtze Basin. Sci. Rep. 2018, 8, 3256. [CrossRef]

16. Agency for Toxic Substances and Disease Registry (ATSDR). Toxicological Profile for Arsenic. Available online: https://atsdr.cdc. gov/toxprofiles/tp2.pdf (accessed on 11 January 2021).

17. Agency for Toxic Substances and Disease Registry (ATSDR). Toxguide for Nickel. Available online: https://atsdr.cdc.gov/ toxguides/toxguide-15.pdf (accessed on 11 January 2021).

18. Agency for Toxic Substances and Disease Registry (ATSDR). Toxguide for Zinc. Available online: https://atsdr.cdc.gov/ toxguides/toxguide-60.pdf (accessed on 11 January 2021).

19. Agency for Toxic Substances and Disease Registry (ATSDR). Toxguide for Lead. Available online: https://atsdr.cdc.gov/ toxguides/toxguide-13.pdf (accessed on 11 January 2021). 
20. Agency for Toxic Substances and Disease Registry (ATSDR). Toxicological Profile for Copper. 2004. Available online: https: //atsdr.cdc.gov/toxprofiles/tp132.pdf (accessed on 11 January 2021).

21. Kowalska, J.B.; Mazurek, R.; Gąsiorek, M.; Zaleski, T. Pollution indices as useful tools for the comprehensive evaluation of the degree of soil contamination-A review. Environ. Geochem. Health 2018, 40, 2395-2420. [CrossRef]

22. Adimalla, N.; Qian, H.; Nandan, M.; Hursthouse, A. Potentially toxic elements (PTEs) pollution in surface soils in a typical urban region of south India: An application of health risk assessment and distribution pattern. Ecotoxicol. Environ. Saf. 2020, $203,111055$. [CrossRef] [PubMed]

23. Jadoon, S.; Muhammad, S.; Hilal, Z.; Ali, M.; Khan, S.; Khattak, N.U. Spatial distribution of potentially toxic elements in urban soils of Abbottabad city, (N Pakistan): Evaluation for potential risk. Microchem. J. 2019, 153, 104489. [CrossRef]

24. Egbueri, J.C. Groundwater quality assessment using pollution index of groundwater (PIG), ecological risk index (ERI) and hierarchical cluster analysis (HCA): A case study. Groundw. Sustain. Dev. 2019, 10, 100292. [CrossRef]

25. Paul, V.; Sankar, M.; Vattikutti, S.; Dash, P.; Arslan, Z. Pollution assessment and land use land cover influence on trace metal distribution in sediments from five aquatic systems in southern USA. Chemosphere 2020, 263, 128243. [CrossRef] [PubMed]

26. Wold, S.; Esbensen, K.; Geladi, P. Principal component analysis. Chemom. Intell. Lab. Syst. 1987, 2, 37-52. [CrossRef]

27. Sinharay, S. An Overview of Statistics in Education. In International Encyclopedia of Education, 3rd ed.; Elsevier: Amsterdam, The Netherlands, 2010; pp. 1-11.

28. Pham, V.-D.; Fatimah, M.-S.; Sasaki, A.; Duong, V.-H.; Pham, K.-L.; Susan, P.; Watanabe, T. Seasonal variation and source identification of heavy metal(loid) contamination in peri-urban farms of Hue city, Vietnam. Environ. Pollut. 2021, $278,116813$. [CrossRef]

29. Choi, J.Y.; Jeong, H.; Choi, K.-Y.; Hong, G.H.; Yang, D.B.; Kim, K.; Ra, K. Source identification and implications of heavy metals in urban roads for the coastal pollution in a beach town, Busan, Korea. Mar. Pollut. Bull. 2020, 161, 111724. [CrossRef] [PubMed]

30. Kim, W.; Song, I.; Shin, J.; Oh, C.; Kim, E.; Kim, K.; Kim, H.; Kim, J.; Choi, Y. A Study on Soil Contamination of Children's Parks within the Gyeonggi-do Province Area. Korean J. Environ. Health Sci. 2017, 43, 233-239. [CrossRef]

31. Lee, C.D.; Lee, Y.J.; Cho, N.Y. Evaluation of heavy metal pollution in soil on the playgrounds for children in I area. Korean J. Environ. Health Soc. 2001, 27, 57-62.

32. Kim, K.H.; Park, S.N. Distribution of $\mathrm{NO}^{3-}, \mathrm{SO}_{4}{ }^{2-}$ and metals in some urban-forest soils of central Korea. Korean. J. Environ. Agric. 2000, 19, 351-357.

33. Chon, H.-T.; Kim, K.-W.; Kim, J.-Y. Metal contamination of soils and dusts in Seoul metropolitan city, Korea. Environ. Geochem. Health 1995, 17, 139-146. [CrossRef]

34. Park, K.H. Pb, Cu, Zn contaminants and their correlation of soil, leave and bark of Ginkgo.B and ambient air adjacent to a heavy traffic road side. Korean J. Environ. Health Soc. 1992, 18, 19-25.

35. Benhaddya, M.L.; Boukhelkhal, A.; Halis, Y.; Hadjel, M. Human Health Risks Associated with Metals from Urban Soil and Road Dust in an Oilfield Area of Southeastern Algeria. Arch. Environ. Contam. Toxicol. 2015, 70, 556-571. [CrossRef]

36. Yuswir, N.S.; Praveena, S.M.; Aris, A.Z.; Ismail, S.N.S.; Hashim, Z. Health Risk Assessment of Heavy Metal in Urban Surface Soil (Klang District, Malaysia). Bull. Environ. Contam. Toxicol. 2015, 95, 80-89. [CrossRef]

37. Wuana, R.A.; Okieimen, F.E. Heavy Metals in Contaminated Soils: A Review of Sources, Chemistry, Risks and Best Available Strategies for Remediation. ISRN Ecol. 2011, 2011, 1-20. [CrossRef]

38. USEPA. Guidance for Data Quality Assessment: Practical Methods for Data Analysis, EPA QA/G-9, QA00. 2000. Available online: https: / / epa.gov/sites/default/files/2015-06-documents/g9-final.pdf (accessed on 19 January 2021).

39. Helsel, D.R. Nondetects and Data Analysis: Statistics for Censored Environmental Data, 1st ed.; Wiley-Interscience: Hoboken, NJ, USA, 2005.

40. Shoari, N.; Dubé, J.-S. Toward improved analysis of concentration data: Embracing nondetects. Environ. Toxicol. Chem. 2017, 37, 643-656. [CrossRef]

41. National Institute of Environmental Research (NIER). Evaluation and Establishment of the Soil Pollution Standards (I), South Korea. 2004. Available online: https:/ / ecolibrary.me.go.kr/nier/\#/ (accessed on 3 March 2021). (In Korean)

42. National Institute of Environmental Research (NIER). Evaluation and Establishment of the Soil Pollution Standards (II), South Korea. 2005. Available online: https:/ / ecolibrary.me.go.kr/nier/\#/ (accessed on 3 March 2021). (In Korean)

43. Rijkswaterstaat Ministry of Infrasturcture and the Environment. Into Dutch Soils, WVL1114VH2374. 2014. Available online: https:/ / rwsenvironment.eu/subjects/soil/publications/ (accessed on 28 January 2021).

44. British Geological Survey (BGS), Normal Background Concentrations (NBCs) of Contaminants in English and Welsh Soils. Available online: https://bgs.ac.uk/geology-projects/applied-geochemistry/g-base-environmental-geochemistry/nbc-defraproject (accessed on 28 January 2021).

45. Ander, E.L.; Johnson, C.C.; Cave, M.; Palumbo-Roe, B.; Nathanail, C.P.; Lark, R. Methodology for the determination of normal background concentrations of contaminants in English soil. Sci. Total. Environ. 2013, 454-455, 604-618. [CrossRef] [PubMed]

46. Hakanson, L. An ecological risk index for aquatic pollution control.a sedimentological approach. Water Res. 1980, 14, 975-1001. [CrossRef]

47. Pulles, T.; van der Gon, H.D.; Appelman, W.; Verheul, M. Emission factors for heavy metals from diesel and petrol used in European vehicles. Atmos. Environ. 2012, 61, 641-651. [CrossRef] 
48. Piscitello, A.; Bianco, C.; Casasso, A.; Sethi, R. Non-exhaust traffic emissions: Sources, characterization, and mitigation measures. Sci. Total Environ. 2021, 766, 144440. [CrossRef]

49. Chen, X.; Lu, X. Contamination characteristics and source apportionment of heavy metals in topsoil from an area in Xi'an city, China. Ecotoxicol. Environ. Saf. 2018, 151, 153-160. [CrossRef]

50. Pam, A.A.; Sha'Ato, R.; Offem, J.O. Evaluation of metals in soils around auto mechanic workshop clusters in Gboko and Makurdi, Central Nigeria. J. Environ. Chem. Ecotox. 2013, 5, 298-306. [CrossRef]

51. Jeong, H.; Choi, J.Y.; Ra, K. Characteristics of Heavy Metal Pollution in Road Dust from Urban Areas: Comparison by Land Use Types. J. Environ. Anal. Health Toxicol. 2020, 23, 101-111. [CrossRef]

52. Khan, A.B.; Kathi, S. Evaluation of heavy metal and total petroleum hydrocarbon contamination of roadside surface soil. Int. J. Environ. Sci. Technol. 2014, 11, 2259-2270. [CrossRef]

53. Hamzeh, M.A.; Aftabi, A.; Mirzaee, M. Assessing geochemical influence of traffic and other vehicle-related activities on heavy metal contamination in urban soils of Kerman city, using a GIS-based approach. Environ. Geochem. Health 2011, 33, 577-594. [CrossRef]

54. National Environmental Research Institute (NERI). Heavy Metal Emissions for Danish Road Transport; Technical Report No. 780; National Environmental Research Institute: Roskile, Denmark, 2010.

55. Coufalík, P.; Matoušek, T.; Křůmal, K.; Vojtíšek-Lom, M.; Beránek, V.; Mikuška, P. Content of metals in emissions from gasoline, diesel, and alternative mixed biofuels. Environ. Sci. Pollut. Res. 2019, 26, 29012-29019. [CrossRef] [PubMed]

56. MobilTM. Mobil 1 Engine Oil Product Guide. Available online: https://www.mobil.com (accessed on 9 February 2021).

57. Penrite Oil. Zinc in Engine Oil Updated (Technical Bulletin No. 149). Available online: http://www.penriteoil.co.nz/tech_pdfs/ 149\%20LATEST\%2020ZINC\%20LEVELS.pdf (accessed on 9 February 2021).

58. Lucasoil Products Inc. Lucas Motor Oil \& Motorcycle Oil Typical Zinc Values. Available online: https://www.lucasoil.com/pdf/ Zinc_Values_MotorcycleOil.pdf (accessed on 9 February 2021).

59. Pant, P.; Harrison, R.M. Estimation of the contribution of road traffic emissions to particulate matter concentrations from field measurements: A review. Atmos. Environ. 2013, 77, 78-97. [CrossRef]

60. Adachi, K.; Tainosho, Y. Characterization of heavy metal particles embedded in tire dust. Environ. Int. 2004, 30, 1009-1017. [CrossRef] [PubMed]

61. Shayler, H.; McBride, M.; Harrison, E. Sources and Impacts of Contaminants in Soils; Cornell Waste Management Institute, Department of Crop \& Soil Sciences, Cornell University: New York, NY, USA, 2009. Available online: https:/ / ecommons.cornell. edu/handle/1813/14282 (accessed on 23 February 2021).

62. Wei, B.; Yang, L. A review of heavy metal contaminations in urban soils, urban road dusts and agricultural soils from China. Microchem. J. 2010, 94, 99-107. [CrossRef]

63. Saito, H.; Sutton, M.; Zhao, P.; Lee, S.D.; Magnuson, M. Review of technologies for preventing secondary transport of soluble and particulate radiological contamination from roadways, roadside vegetation, and adjacent soils. Environ. Adv. 2020, 1, 100003 [CrossRef]

64. Bagshaw, N. Lead alloys: Past, present and future. J. Power Source 1995, 53, 25-30. [CrossRef]

65. De Silva, S.; Ball, A.S.; Indrapala, D.V.; Reichman, S.M. Review of the interactions between vehicular emitted potentially toxic elements, roadside soils, and associated biota. Chemosphere 2020, 263, 128135. [CrossRef]

66. Ferreira, A.J.D.; Soares, D.; Serrano, L.M.V.; Walsh, R.P.D.; Dias-Ferreira, C.; Ferreira, C.S.S. Roads as sources of heavy metals in urban areas. The Covões catchment experiment, Coimbra, Portugal. J. Soils Sedim. 2016, 16, 2622-2639. [CrossRef]

67. Thorpe, A.; Harrison, R.M. Sources and properties of non-exhaust particulate matter from road traffic: A review. Sci. Total Environ. 2008, 400, 270-282. [CrossRef] [PubMed]

68. Sager, M. Urban Soils and Road Dust-Civilization Effects and Metal Pollution-A Review. Environments 2020, 7, 98. [CrossRef]

69. Chen, H.Y. The distributional characteristics of $\mathrm{Cu}$ and else 13 kinds of elements in city soil of Fuzhou. Geol. Fujian 2008, 27, 211-218. (In Chinese)

70. Taghipour, H.; Mosaferi, M.; Armanfar, F.; Gaemmagami, S.J. Heavy metals pollution in the soils of suburban areas in big cities: A case study. Int. J. Environ. Sci. Technol. 2013, 10, 243-250. [CrossRef]

71. Birke, M. Urban Geochemistry: Investigations in the Berlin Metropolitan Area. Environ. Geochem. Health 2000, 22, 233-248. [CrossRef]

72. European Commission (EU). Particulates: Characterisation of Exhaust Particulate Emissions from Road Vehicles, Deliverable 8-Measurement of Non-Exhaust Particulate Matter. European Commission 5th Framework Programme. 2004. Available online: https:/ / ec.europa.eu/transport/road_safety/sites/default/files/pdf/projects_sources/particulates_d8.pdf (accessed on 23 February 2021).

73. Chicharromartin, A.; Calarivero, V.; Larreamarin, M.; Martín, A.C.; Rivero, M.V.C.; Marín, M.L. Contamination by heavy metals in soils in the neighbourhood of a scrapyard of discarded vehicles. Sci. Total Environ. 1998, 212, 145-152. [CrossRef]

74. Olafisoye, O.B.; Adefioye, T.; Osibote, O.A. Metals contamination of water, soil and plants around an electronic waste dumpsite. Pol. J. Environ. Stud. 2013, 22, 1431-1439.

75. Ololade, I.A. An Assessment of Heavy-Metal Contamination in Soils within Auto-Mechanic Workshops Using Enrichment and Contamination Factors with Geoaccumulation Indexes. J. Environ. Prot. 2014, 5, 970-982. [CrossRef] 
76. Ajah, K.C.; Ademiluyi, J.; Nnaji, C.C. Spatiality, seasonality and ecological risks of heavy metals in the vicinity of a degenerate municipal central dumpsite in Enugu, Nigeria. J. Environ. Health Sci. Eng. 2015, 13, 1-15. [CrossRef]

77. Nabulo, G.; Oryem-Origa, H.; Diamond, M. Assessment of lead, cadmium, and zinc contamination of roadside soils, surface films, and vegetables in Kampala City, Uganda. Environ. Res. 2006, 101, 42-52. [CrossRef] [PubMed]

78. Environment Agency Austria. Austria's Informative Inventory Report (IIR). 2012. Available online: https://umweltbundesamt. at/fileadmin/site/publikationen/REP0380.pdf (accessed on 23 February 2021).

79. Korean Ministry of Environment (KMOE). Investigation of Fugitive Dust Emission \& Risk Caused by Tire and Brake Pad Wear. 2012. Available online: http:/ / dl.nanet.go.kr/law/SearchDetailView.do?cn=MONO201316959 (accessed on 23 February 2021). (In Korean).

80. US EPA. Emission Factor Documentation for AP-42 Section 13.2.1 Paved Roads. 2011. Available online: https://www3.epa.gov/ ttn/chief/ap42/ch13/bgdocs/b13s0201.pdf (accessed on 23 February 2021).

81. Ondráček, J.; Schwarz, J.; Ždímal, V.; Andělová, L.; Vodička, P.; Bízek, V.; Tsai, C.-J.; Chen, S.-C.; Smolík, J. Contribution of the road traffic to air pollution in the Prague city (busy speedway and suburban crossroads). Atmos. Environ. 2011, 45, 5090-5100. [CrossRef]

82. Harrison, R.M.; Jones, A.M.; Gietl, J.; Yin, J.; Green, D.C. Estimation of the contributions of brake dust, tire wear, and resus-pension to non-exhaust traffic particles derived from atmospheric measurements. Environ. Sci. Technol. 2012, 46, 6523-6529. [CrossRef] [PubMed]

83. Hagino, H.; Oyama, M.; Sasaki, S. Laboratory testing of airborne brake wear particle emissions using a dynamometer system under urban city driving cycles. Atmos. Environ. 2016, 131, 269-278. [CrossRef]

84. Gustafsson, M.; Blomqvist, G.; Gudmundsson, A.; Dahl, A.; Swietlicki, E.; Bohgard, M.; Lindbom, J.; Ljungman, A. Properties and toxicological effects of particles from the interaction between tyres, road pavement and winter traction material. Sci. Total Environ. 2008, 393, 226-240. [CrossRef] 